\title{
Single bulb garlic oil improves interleukin-6 via decreased reactive oxygen species (ROS) in high-fat diet male mice
}

\author{
Riza Rahayu Ilmawati ${ }^{*}$, Abdul Gofur ${ }^{* *}$, and Sri Rahayu Lestari ${ }^{* *}$
}

\begin{abstract}
BACKGROUND

High-fat diet (HFD) is highly responsible for the development of excessive reactive oxygen species (ROS). ROS and low-density lipoprotein (LDL) then trigger macrophage activation to secrete interleukin-6 (IL-6). Single bulb garlic or in Indonesian called bawang lanang is traditional medicine that possesses strong antioxidant properties. This study aimed to evaluate the effect of single bulb garlic oil (SBGO) on ROS, IL-6, and lymphocyte density in HFD-fed male mice.
\end{abstract}

\section{METHODS}

This was an experimental study on 24 male mice randomly subdivided into 6 groups: one group was fed a normal diet, whereas the remaining five groups were fed HFD for 45 days and were then treated with single bulb garlic oil $0 \mathrm{mg} / \mathrm{kg}$, simvastatin $26 \mathrm{mg} / \mathrm{kg} \mathrm{BW}$, single bulb garlic oil $12.5 \mathrm{mg} /$ $\mathrm{kg} \mathrm{BW}, 25 \mathrm{mg} / \mathrm{kg} \mathrm{BW}$, and $50 \mathrm{mg} / \mathrm{kg} \mathrm{BW}$ respectively for the next 35 days. At the end of treatment, the mice were dissected for collection of (i) serum in order to measure ROS and IL-6 levels using ELISA, (ii) aortas to measure IL-6 expression using immunohistochemistry-fluorescence (IHC-F) and to obtain lymphocytes from bone marrow and spleen which were then counted using a light microscope.

\section{RESULTS}

Our results indicated that SBGO decreased the ROS level, IL-6 level, IL-6 expression, and lymphocyte density in HFD mice. SBGO $12.5 \mathrm{mg} / \mathrm{kg} \mathrm{BW}$ is the optimum dose in our study to reduce inflammation in HFD male mice.

\section{CONCLUSION}

SBGO is useful to reduce inflammation and improve antioxidant imbalance, thus might be a potential antiatherogenic agent.

Keywords: Single bulb garlic, ROS, IL-6, lymphocyte, male mice
*Master Program of Biology, Department of Biology, Faculty of Mathematics and Natural Sciences, Universitas Negeri Malang **Department of Biology, Faculty of Mathematics and Natural Sciences, Universitas Negeri Malang

\section{Correspondence:}

Sri Rahayu Lestari

Department of Biology,

Faculty of Mathematics and Natural Sciences, Universitas Negeri Malang J1 Semarang No. 5, Malang 65145, Jawa Timur, Indonesia

Phone : +62341 588077

Email: srirahayulestari@um.ac.id ORCID ID: orcid.org/0000-00032208-4156

Date of first submission, December 2, 2018

Date of final revised submission, May 14,2019

Date of acceptance, May 15, 2019

This open access article is distributed under a Creative Commons AttributionNon Commercial-Share Alike 4.0 International License

Cite this article as: Ilmawati RR, Gofur A, Lestari SR. Single bulb garlic oil improves interleukin-6 via decreased reactive oxygen species (ROS) in highfat diet male mice. Univ Med 2019; 38:100-7. doi: 10.18051/UnivMed. 2018.v38.100-107 


\section{INTRODUCTION}

Atherosclerosis is a chronic inflammatory disease of the arterial wall due to oxidation of lipoprotein that stimulates the adaptive immune response, ${ }^{(1)}$ the disease ultimately causing coronary heart disease. ${ }^{(2)}$ The prevalence of coronary heart disease in 2013 in Indonesia was about 883,447 people. $^{(3)}$ Death from cardiovascular disease, especially coronary heart disease, is estimated to increase by 23.3 million in 2030. The primary cause of atherosclerosis is an unhealthy lifestyle. ${ }^{(4)}$

The high-fat diet causes fat deposits to increase leading to excessive production of lowdensity lipoprotein (LDL) and reactive oxygen species (ROS), including superoxide, peroxyl, and hydroxyl radicals. ${ }^{(5)}$ Reactive oxygen species causes LDL to be easily oxidized into oxidized low-density lipoprotein (Ox-LDL) thus causing vascular injury and organ dysfunction. ${ }^{(6)}$ Oxidized low-density lipoprotein will activate endothelial cells in blood vessel walls. Thus monocytes are activated into macrophages and cause scavenger receptor (SR) expression. Macrophage activation triggers the activation of $\mathrm{CD}^{+}{ }^{+} \mathrm{T}$-cells. Macrophages and Th17 lymphocytes secrete the interleukin-6 (IL-6) pro-inflammatory cytokine ${ }^{(7)}$ which induces intercellular adhesion molecule (ICAM) in endothelial cells. Further, IL-6 triggers inflammation by increasing the production of neutrophils in infected sites. ${ }^{(8)}$

Simvastatin is the general treatment for atherosclerosis. The use of simvastatin has side effects called simvastatin-associated symptoms. ${ }^{(9)}$ Nowadays, herbal medicines are preferable to synthetic drugs. Herbal therapy is expected to be safe with fewer side effects on people with atherosclerosis. ${ }^{(10)}$ Herbal medicine offers great opportunities for exploration since Indonesia has many plant natural resources. One of the plants which are traditionally used as medicine is single bulb garlic.

Single bulb garlic, or bawang lanang in Indonesian, is a traditional medicine for which the plant is grown in extreme conditions. Single bulb garlic has a characteristically stronger odor than common garlic. ${ }^{(11)}$ Another advantageous effect is that single bulb garlic has a 3.5 -fold greater total phenolic content than common garlic. ${ }^{(12)}$ Two of the most critical organosulfur compounds in garlic are the non-volatile amino acid $\gamma$-glutamyl-S-alk(en)yl-L-cysteine and essential oil of S-alk(en)yl-cysteine sulphoxides or alliin. ${ }^{(13)}$ The enzymatic reaction of $\gamma$-glutamylS-alk(en)yl-L-cysteine produces allicin. ${ }^{(14)}$ Allicin is the primary active compound in garlic which has been reported to inhibit ROS and NADPH oxidase in HUVECs. ${ }^{(15)}$ A previous study reported that aqueous garlic extract exerts antioxidant activity by scavenging ROS. ${ }^{(16)}$ In addition, garlic oil extract was reported to improve regulatory T cells in HFD mice. ${ }^{(17)}$

However, there are as yet few reports about the beneficial effect of using oil extract of single bulb garlic to directly scavenge ROS and ameliorate interleukin-6. Single bulb garlic is expected to inhibit the formation of ROS as the free radicals, thus inhibiting the secretion of IL- 6 and decreasing the number of lymphocytes in highfat diet (HFD)-fed mice.

\section{METHODS}

\section{Research design}

This was experimental research using a completely randomized design. The research was carried out at the Human and Animal Physiology Laboratory, Universitas Negeri Malang; the Physiology Laboratory, Faculty of Medicine, Central Life Science Laboratory, and the BioScience Institute, Brawijaya University, Malang, from April to November 2017.

\section{Single bulb garlic oil preparation}

Single bulb garlic oil was prepared by the Soxhlet method based on the procedure conducted at the Phytochemical Laboratory of the Batu Materia Medica Technical Implementing Unit (UPT Materia Medica Batu) as follows: 1 $\mathrm{kg}$ of air-dried single bulb garlic was extracted with $4.5 \mathrm{~L}$ of $n$-hexane (EMSURE®, cat no: 
104367). The resulting extract was $3 \mathrm{~mL}$ then evaporated using a rotary evaporator (IKA ${ }^{\circledR} \mathrm{RV}$ 10 Basic V). The single bulb garlic oil stock (3 $\mathrm{mL}$ ) was then prepared for treatment to constitute doses of $12.5 \mathrm{mg} / \mathrm{kg} \mathrm{BW}, 25 \mathrm{mg} / \mathrm{kg}$ $\mathrm{BW}$, and $50 \mathrm{mg} / \mathrm{kg} \mathrm{BW}$, respectively, diluted in corn oil (Tropicana slim ${ }^{\circledR}$, Nutrifood, Indonesia).

\section{Study subject and sample size determination}

Mice were obtained from CV. Galaxy Science, Jember. The mice were Balb/C strain males aged 8 weeks and weighing $28 \mathrm{~g} \pm 2 \mathrm{~g}$. The number of required mice was determined based on Federer's formula. Twenty-eight male $\mathrm{Balb} / \mathrm{C}$ mice housed in individual plastic cages were acclimatized for 1 week. The mice were randomly divided into two major groups, i.e. one group on normal diet (ND) $(n=4)$ and five groups on HFD $(n=20)$. The normal diet concentrate consisted of $63 \%$ carbohydrate, $16 \%$ protein, $3 \%$ fat, $21 \%$ vitamins and minerals (PT. Comfeed Phokpand, Indonesia). The HFD consisted of Hi-Gro Medicated 551 chicken feed (300 g), corn flour (200 g), duck egg yolk (100 g), wheat flour $(50 \mathrm{~g})$, cholic acid $(0.1 \mathrm{~g})$, and waste cooking oil $(0.3 \mathrm{~L})$. The mice were fed the HFD at a dose of $7 \mathrm{~g} /$ day/mouse and ad libitum drinking water for 45 days. The HFD groups were then divided randomly and equally $(n=4)$ into HFD, HFD + Simv (HFD + simvastatin $26 \mathrm{mg} / \mathrm{kg}$ ), and HFD $+\mathrm{P} 1-\mathrm{P} 3$ (HFD + SBGO 12.5, 25, and $50 \mathrm{mg} / \mathrm{kg}$ BW respectively). After 45 days of diet manipulation, the three concentrations of SBGO and simvastatin were administered orally for 35 days consecutively.

\section{Measurement of ROS and IL-6}

At the end of the experiment, the mice were sacrificed through euthanasia (isoflurane 4\%). Blood was collected $( \pm 0.5 \mathrm{~mL})$ from the heart and incubated for 30 minutes at $37^{\circ} \mathrm{C}$, then centrifuged at $10000 \mathrm{rpm}$ for 10 minutes, and the serum collected. ROS and the IL-6 level were measured using ELISA at $450 \mathrm{~nm}$ according to the protocol. Briefly, $20 \mu \mathrm{L}$ serum was mixed with coating buffer (1:20) then incubated at $4{ }^{\circ} \mathrm{C}$ overnight. The well plate was then washed with PBS-Tween $0.2 \%$, coated with anti-IL-6 primary antibody (cat. no. SC73319, Santa Cruz Biotechnology, USA) or ROS (E1654Mo: BT-Lab) (1:1000) in assay buffer, and incubated for 2 hours at room temperature. After that, the well plate was washed with PBSTween $-0.2 \%$, then coated with secondary antibody, i.e. alkaline phosphatase (AP)conjugated goat anti-rabbit IgG in assay buffer (1:2000), incubated for 1 hour at room temperature, and washed with PBS-T $0.2 \%$. To the well plate was added streptavidin horseradish peroxidase (SA-HRP) in assay buffer (1:2000) and incubated for 1 hour at room temperature. The well plate was washed with PBS-Tween$0.2 \%$, then $3,3^{\prime}, 5,5^{\prime}$-tetramethylbenzidine (TMB) chromogenic reagent for peroxidase was added, and incubated for 20 minutes at room temperature. Finally, $1 \mathrm{~N} \mathrm{HCl}$ as the stop solution was added and the results read immediately with an ELISA Reader (Bio-Rad Benchmark, Japan) at $450 \mathrm{~nm}$.

\section{Immunohistochemistry}

From each mouse, the aorta was separated from the heart and fixed in buffered formalin $10 \%$. Each aorta was then prepared into slides for immunohistochemistry-fluorescence (IHCF) with IL-6 as the primary antibody. Firstly, the aorta slides were incubated with primary antibody and $2 \%$ bovine serum albumin (BSA) in the ratio of 1:1000 for one hour. Then the slide was treated with the secondary antibody, namely goat anti-mouse $\mathrm{IgG}$ fluorescein isothiocyanate (FITC) in 2\% complete BSA (1:1500), and incubated for one hour. The slides were then washed using complete PBS pH 7.4 for three times, dried and covered with cover glasses. The slides were observed using a fluorescence microscope (FSX-100), and IL-6 expression was measured (intensity $/ \mathrm{mm}^{2}$ ). ${ }^{(18)}$

\section{Measurement of lymphocyte density}

Lymphocytes were taken from the spleen and bone marrow. Briefly, spleen lymphocytes 
were minced using a syringe holder. The homogenate was put into a $15 \mathrm{~mL}$ polypropylene tube. ${ }^{(19)}$ Bone marrow lymphocytes were isolated by cutting both ends of the femur then flushing out using $1 \mathrm{~mL}$ of phosphate buffered saline (PBS). The suspension was then put into a $15 \mathrm{~mL}$ polypropylene centrifuge tube. ${ }^{(20)}$ The lymphocyte density was calculated under the light microscope using a hemocytometer and trypan blue staining. ${ }^{(21)}$ The number of lymphocytes was counted in 5 large squares of the hemocytometer. The lymphocyte density was calculated according to the formula in Dwijayanti et al. ${ }^{(21)}: \Sigma$ cells $=\Sigma$ cells counted $\mathrm{x} 5$ to correct for the 1:5 dilution from the Trypan Blue addition x $10^{4}$ cells $/ \mathrm{ml}$

\section{Statistical analysis}

Data were expressed as mean \pm standard deviation (SD). One-Way ANOVA was performed to assess significant differences $(p<0.05)$ between groups after SGBO treatment followed by Duncan Multiple Range Test (DMRT) as post hoc test. One-Way ANOVA was performed using SPSS 16.0 for Windows (SPSS Inc., Chicago, IL, USA). The number of lymphocytes was analyzed using the KruskalWallis $\mathrm{H}$ test at the level of confidence of $95 \%$ $(\alpha=0.05)$ and continued with the Mann-Whitney $\mathrm{U}$ test.

\section{Ethical clearance}

The research had obtained approval from the Ethics Committee of Brawijaya University under no. 880-KEP-UB.

\section{RESULTS}

Single bulb garlic oil effects on ROS, IL-6 level, expression of IL- 6 in the aorta, and lymphocyte density in the spleen and bone marrow in male mice fed on the high-fat diet. Our results showed that ROS level was significantly increased in HFD mice compared to the normal ones $(\mathrm{p}<0.05)$ (Table 1). SBGO treatment at a dose of $12.5 \mathrm{mg} / \mathrm{kg}$ BW significantly reduced the ROS level compared to HFD $(p<0.05)$. Interestingly, SBGO 25 and $50 \mathrm{mg} / \mathrm{kg} \mathrm{BW}$ decreased ROS level but did not significantly differ from HFD. Our findings showed that SBGO at $12.5 \mathrm{mg} / \mathrm{kg}$ BW reduced ROS towards near normal levels. The IL-6 level increased significantly in HFD mice compared to the normal group $(\mathrm{p}<0.05)$. SBGO treatment at a dose of $12.5 \mathrm{mg} / \mathrm{kg}$ BW significantly reduced the IL-6 level compared to HFD $(\mathrm{p}<0.05)$. Interestingly, SBGO 25 and $50 \mathrm{mg} / \mathrm{kg}$ BW failed to decrease IL-6 level and were not significantly different compared to HFD. Our findings showed that SBGO at $12.5 \mathrm{mg} / \mathrm{kg}$ BW reduced IL-6 towards near normal levels (Table 1).

Table 1. ROS and IL-6 level, IL-6 expression in aorta, and lymphocyte density of mice fed a normal or high fat diet after treatment with/without SBGO

\begin{tabular}{|c|c|c|c|c|c|c|c|}
\hline & \multicolumn{6}{|c|}{ Treatment group } & \multirow{2}{*}{$\begin{array}{c}\mathbf{p} \\
\text { value }\end{array}$} \\
\hline & $N(n=4)$ & $K+(n=4)$ & $K-(n=4)$ & $P 1(n=4)$ & P2 $(n=4)$ & P3 $(n=4)$ & \\
\hline ROS level (pg/mL) & $\begin{array}{c}286.59^{\mathrm{a}} \pm \\
6.71\end{array}$ & $\begin{array}{c}292.43^{\mathrm{ab}} \pm \\
9.24\end{array}$ & $\begin{array}{c}302.47^{b} \pm \\
4.02\end{array}$ & $\begin{array}{c}286.12^{\mathrm{a}} \pm \\
4.99\end{array}$ & $\begin{array}{c}298.88^{\mathrm{b}} \pm \\
4.54\end{array}$ & $\begin{array}{c}300^{\mathrm{b}} \\
\pm 6.85\end{array}$ & 0.05 \\
\hline IL-6 level (pg/mL) & $\begin{array}{c}225.91^{\mathrm{a}} \pm \\
56.98\end{array}$ & $\begin{array}{c}275.92^{\mathrm{a}} \pm \\
87.72\end{array}$ & $\begin{array}{c}404.04^{\mathrm{b}} \pm \\
23.51\end{array}$ & $\begin{array}{c}279.53^{\mathrm{a}} \pm \\
86.77\end{array}$ & $\begin{array}{c}445.61^{\mathrm{b}} \pm \\
115.81\end{array}$ & $\begin{array}{c}396.12^{\mathrm{b}} \pm \\
52.46\end{array}$ & 0.05 \\
\hline $\begin{array}{l}\text { IL- } 6 \text { expression in } \\
\text { the aorta } \\
\text { (intensity } / \mathrm{mm}^{2} \text { ) }\end{array}$ & $\begin{array}{l}58.57^{\mathrm{a}} \\
\pm 2.99\end{array}$ & $\begin{array}{l}59.61^{\mathrm{a}} \\
\pm 4.77\end{array}$ & $\begin{array}{l}70.6^{\mathrm{b}} \\
\pm 3.24\end{array}$ & $\begin{array}{l}59.8^{\mathrm{a}} \\
\pm 2.6\end{array}$ & $\begin{array}{l}66.13^{\mathrm{b}} \\
\pm 4.77\end{array}$ & $\begin{array}{c}66.97^{\mathrm{b}} \\
\pm 2.1\end{array}$ & 0.05 \\
\hline $\begin{array}{l}\text { Lymphocyte density } \\
\left(1 \times 10^{4}\right)^{*}\end{array}$ & $\begin{aligned} & 906^{\mathrm{a}} \\
& \pm 28.12 \\
&\end{aligned}$ & $\begin{array}{c}933.25^{\mathrm{a}} \pm \\
72.75\end{array}$ & $\begin{aligned} & 3788^{\mathrm{a}} \\
\pm & 241.27\end{aligned}$ & $\begin{array}{c}962^{\mathrm{a}} \\
\pm 105.48\end{array}$ & $\begin{aligned} & 968^{\mathrm{a}} \\
\pm & 47.07\end{aligned}$ & $\begin{array}{c}984.75^{\mathrm{a}} \pm \\
73.84\end{array}$ & 0.05 \\
\hline
\end{tabular}

ROS : reactive oxygen species; IL : interleukin; $\mathrm{N}=$ normal diet, $\mathrm{K}+=\mathrm{HFD}+\operatorname{simvastatin} 26 \mathrm{mg} / \mathrm{kg} \mathrm{BW}, \mathrm{K}-=\mathrm{HFD}$ only, $\mathrm{P} 1=\mathrm{P} 3=\mathrm{HFD}+\mathrm{SBGO} 12.5,25$, and $50 \mathrm{mg} / \mathrm{kg} \mathrm{BW}$ respectively. The same notation indicates no differences between groups based on DMRT test $(\mathrm{p}<0.05) . *=$ Data analysis based on Kruskal-Wallist test followed by Mann-Whitney test $(\mathrm{p} 0.05)$ 

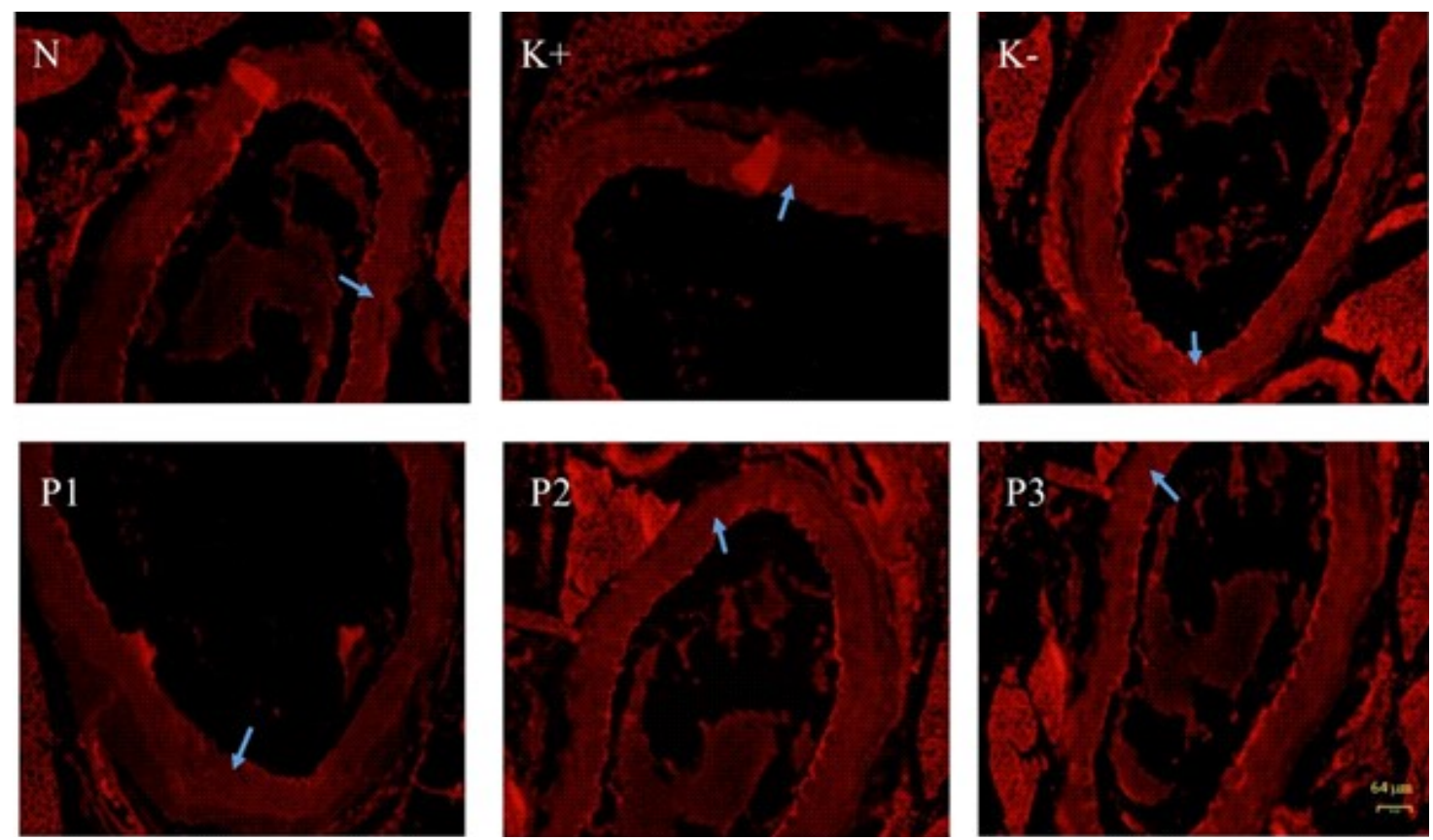

Figure 1. IL-6 expression in the aorta of mice at the end of study. Blue arrow indicates the expression of IL- 6 in the aorta. $\mathrm{N}=$ normal diet, $\mathrm{K}+=\mathrm{HFD}+\operatorname{simvastatin} 26 \mathrm{mg} / \mathrm{kg} \mathrm{BW}, \mathrm{K}-=$ HFD only, P1 = HFD + SBGO $12.5 \mathrm{mg} / \mathrm{kg}$ BW, P2 =

$\mathrm{HFD}+\mathrm{SBGO} 25 \mathrm{mg} / \mathrm{kg} \mathrm{BW}, \mathrm{P} 3=\mathrm{HFD}+\mathrm{SBGO} 50 \mathrm{mg} / \mathrm{kg}$ BW

The expression of IL-6 increased significantly $(\mathrm{p}<0.05)$ in HFD mice compared to the normal group $(\mathrm{p}<0.05)$ (Table 1, Figure 1). SBGO treatment reduced the IL-6 expression compared to HFD alone. Interestingly, SBGO 25 and $50 \mathrm{mg} / \mathrm{kg}$ BW reduced IL-6 expression but were not significantly different compared to HFD. Our findings showed that SBGO at 12.5 $\mathrm{mg} / \mathrm{kg}$ BW reduced IL-6 expression towards near normal levels.

The lymphocyte density both in bone marrow and spleen decreased significantly in HFD mice compared to the normal group $(p<0.05)$. SBGO treatment decreased lymphocyte density compared to HFD. Interestingly, SBGO $12.5,25$ and $50 \mathrm{mg} / \mathrm{kg}$ BW decreased lymphocytes but not significantly different compared with the normal group (Table 1).

\section{DISCUSSION}

Our recent findings suggest that SBGO suppresses the production of ROS in mice fed a high-fat diet. These findings are in line with a previous study conducted by Basu and Sur ${ }^{(22)}$ which reported that S-allyl cysteine protected cells from $\mathrm{H}_{2} \mathrm{O}_{2}$-induced oxidative damage. Moreover, organosulfur compounds in garlic oil may act as radical scavengers of ROS ${ }^{(16,23)}$ and possess antioxidant activity to inhibit lipid peroxidation. ${ }^{(24)}$ Garlic oil increases superoxide dismutase (SOD), catalase, and glutathione peroxidase (GPx) in the endothelial cells of blood vessels. ${ }^{(23)}$ Single bulb garlic acts as a chainbreaking antioxidant for scavenging free radicals. ${ }^{(12)}$ Our recent finding suggests that exogenous antioxidant is needed to help neutralize ROS during HFD administration. The decrease of ROS will inhibit oxidation thus reducing the amounts of Ox-LDL followed by inhibition of macrophages in the immune system. Allicin decreases the level of cholesterol in the blood by reducing cholesterol synthesis, through inhibition of hydroxymethyl-glutaryl-coenzyme A (HMG-CoA) reductase. ${ }^{(25)}$ Allicin and HMGCoA have similar structures, thus allicin is suspected to be a competitive inhibitor of HMGCoA reductase enzyme. Sulfur-containing groups in allicin play an antioxidant role that could decrease Ox-LDL. ${ }^{(15)}$ 
The inhibition of HMG-CoA reductase causes inhibition of cholesterol synthesis in the liver thus the liver secretes lower amounts of cholesterol into the blood. The liver will activate LDL receptors to bind LDL in the blood, thus decreasing cholesterol and LDL in the blood. ${ }^{(25)}$ The decreased LDL level could suppress the secretion of IL- 6 by macrophages and Th17. Our findings suggest that SBGO treatment reduces both IL-6 secretion and IL-6 expression. This is in accordance with the research that garlic oil could suppress the production of the proinflammatory cytokine IL6 through the IL-6/MEK5/ERK5 signaling pathway. ${ }^{(26)}$ Furthermore, garlic components restore the lymphocyte balance during HFD. Our result is consistent with that of a previous study which reported that HFD leads to an imbalanced blood production due to an increase in Gr-1 expression and a decrease in erythrocyte progenitor markers, such as TER- $119^{+} \mathrm{CD} 34^{+}$, TER $119^{+}$, and $\mathrm{TER}^{+} \mathrm{VLA}-4^{+}$during a high-fat fructose diet. ${ }^{(19)}$ We assume that garlic components maintain the balance of blood production and restore the lymphocyte density to close to normal.

Our research indicates that the SBGO dose of $12.5 \mathrm{mg} / \mathrm{kg} \mathrm{BW}$ is the effective dose to inhibit the production of the IL- 6 inflammatory cytokine in mice fed a high-fat diet. SBGO may be used as an alternative agent to reduce free radicals and inflammation caused by HFD. Further research is still needed to explain the detailed mechanism of SBGO in overcoming inflammation caused by HFD. Our findings suggest that SBGO at higher doses cannot suppress the ROS and IL-6 levels. HamlaouiGasmi et al. ${ }^{(27)}$ reported that garlic at high doses triggers a prooxidative state characterized by the Fenton reaction between $\mathrm{H}_{2} \mathrm{O}_{2}$ and free iron inducing tissue calcium repletion.

One limitation of the present study is that we did not measure ROS end-products such as malondialdehyde (MDA). We also did not measure antioxidants to determine their relationship with the development of oxidative stress. Also, we did not measure erythrocyte progenitors, such as TER $-119^{+} \mathrm{CD} 34^{+}$, TER $119^{+}$, and TER ${ }^{+}$VLA $-4^{+}$. Our study is expected to be one of the solutions for the treatment of metabolic disease, particularly that caused by HFD, since garlic is easy to find, is commonly used daily, and is an effective functional food. However, further research still needs to be conducted before single bulb garlic oil can be applied to humans by giving recommendations on appropriate doses.

\section{CONCLUSIONS}

Single bulb garlic oil decreased ROS and IL-6 levels, and lymphocyte density in mice fed a high-fat diet. Based on our research, SBGO $12.5 \mathrm{mg} / \mathrm{kg} \mathrm{BW}$ is the effective dose to reduce ROS and IL-6 levels, and lymphocyte density in mice fed a high-fat diet.

\section{CONFLICT OF INTERESTS}

Competing interests: No relevant disclosures.

\section{ACKNOWLEDGEMENT}

The authors thank all staff of Animal Physiology Laboratory, Central Life Science Laboratory, and BioScience Institute, Brawijaya University, for the use of facilities. The research was part of research by Dr. Sri Rahayu Lestari, M.Si with contract number of DRPM 3.4.8/ UN32.14/LT/2017.

\section{CONTRIBUTORS}

RRI contributed to writing the manuscript, data analysis and interpretation of the data. AG contributed to data collection and processing. SRL contributed to the concept, supervision and critical review. All authors have read and approved the final manuscript. 


\section{REFERENCES}

1. Wu MY, Li CJ, Hou MF, et al. New insights into the role of inflammation in the pathogenesis of atherosclerosis. Int J Mol Sci 2017;18:pii:E2034. doi: 10.3390/ijms18102034.

2. Libby P. History of discovery: inflammation in atherosclerosis. Arter Thromb Vasc Biol 2012;32:2045-51. doi: 10.1161/ATVBAHA.108. 179705 .

3. Kementerian Kesehatan RI Mari menuju masa muda sehat, hari tua nikmat tanpa PTM dengan perilaku cerdik. Jakarta : Kementerian Kesehatan RI; 2014.

4. Spring B, Moller AC, Colangelo LA, et al. Healthy lifestyle change and subclinical atherosclerosis in young adults: coronary artery risk development in young adults (CARDIA) study. Circulation 2014;130:10-7. doi: 10.1161/CIRCULATIONAHA. 113.005445 .

5. Pizzino G, Irrera N, Cucinotta M, et al. Oxidative stress: harms and benefits for human health. Oxid Med Cell Longev 2017;8416763. doi: 10.1155/ 2017/8416763.

6. Tsoupras A, Lordan R, Zabetakis I. Inflammation, not cholesterol, is a cause of chronic disease. Nutrients 2018;10:pii:E604. doi: 10.3390/ nu10050604.

7. Duque GA, Descoteaux A. Macrophage cytokines: involvement in immunity and infectious diseases. Front Immunol 2014;5:1-12. doi:10.3389/fimmu.2014.00491.

8. Bardoel BW, Kenny EF, Sollberger G, et al. The balancing act of neutrophils. Cell Host Microbe 2014;15:526-36. doi:10.1016/j.chom.2014.04.011.

9. Thompson PD, Panza G, Zaleski A, et al. Statinassociated side effects. J Am Coll Cardiol 2016;67:2395-410. doi: 10.1016/j.jacc.2016.02.071.

10. Dalal I, Sengupta M, Paul S, et al. Comparative study of the effect of atorvastatin and garlic extract in experimentally induced hypercholesterolemia in rabbits. Int J Basic Clin Pharmacol 2013;2:397. doi: 10.5455/23192003.ijbcp20130810.

11. Padhar B, Dave AR, Chandola HM, et al. Comparative analytical study of single-bulb and multi-bulb garlic. Int J Ayu Alt Med 2014;2:86-91.

12. Naji KM, Al-Shaibani ES, Alhadi FA, et al. Hepatoprotective and antioxidant effects of single clove garlic against $\mathrm{CCl}$-induced hepatic damage in rabbits. BMC Complement Altern Med 2017;17:411. doi: 10.1186/s12906-017-1916-8.

13. Soto VC, González RE, Sance MM, et al. Organosulfur and phenolic content of garlic (Allium sativum L.) and onion (Allium cepa L.) and its relationship with antioxidant activity. Acta Hortic 2016;1143:277-90. doi: 10.17660/ ActaHortic.2016.1143.39.

14. Deasy A, Dewi R, Kusnadi J, et al. Comparison of the main bioactive compounds and antioxidant activity from garlic water-soluble and garlic oil. KNE Life Sci 2017;2017:20-34. doi: 10.18502/ kls.v3i5.975.

15. Chen X, Pang S, Lin J, et al. Allicin prevents oxidized low-density lipoprotein-induced endothelial cell injury by inhibiting apoptosis and oxidative stress pathway. BMC Complement Altern Med 2016;16:1-6. doi: 10.1186/s12906-0161126-9.

16. Arreola R, Quintero-Fabián S, López-Roa R, et al. Immunomodulation and anti-inflammatory effects of garlic compounds: discovery service for Endeavour College of Natural Health Library. J Immunol Res 2015;401630. doi: 10.1155/2015/ 401630.

17. Lestari SR, Rifa'i M. Regulatory T cells and antiinflammatory cytokine profile of mice fed a highfat diet after single-bulb garlic (Allium sativum L.) oil treatment. Trop J Pharm Res 2018;17:215762. doi: 10.22146/jtbb.33498.

18. Gofur A, Witjoro A, Ningtiyas EW, et al. The ameliorative effect of black soybean and purple sweet potato to improve sperm quality through suppressing reactive oxygen species (ROS) in type 2 diabetes mellitus rat (Rattus novergicus). Science Asia 2018;44:303-10. doi: 10.2306/ scienceasia1513-1874.2018.44.303.

19. Safitri YD, Atho'illah MF, Nur'aini FD, et al. The effects of elicited soybean (Glycine max) extract on hematopoietic cells of high fat-fructose diet Balb/C mice model. Jordan J Biol Sci 2018;11:2416.

20. Atho'illah MF, Safitri YD, Nur'aini FD, et al. Soybean extract suppresses B cell activation through TLR3/TLR4 in high fat-high fructose diet mice. Turkish J Immunol 2018;6:95-103. doi: 10.25002/tji.2018.866.

21. Dwijayanti DR, Djati MS, Rifa'i M. The role of VipAlbumin ${ }^{\circledR}$ as an immunostimulatory agent for controlling homeostasis and proliferation of lymphoid cells. Cent Eur J Immunol 2016;41:31-8. doi: 10.5114/ceji.2016.58814.

22. Basu C, Sur R. S-Allyl cysteine alleviates hydrogen peroxide induced oxidative injury and apoptosis through upregulation of Akt / Nrf-2 / HO-1 signaling pathway in HepG2 cells. BioMed Res Int 2018. Article ID 3169431, 14 pages. https:/ /doi.org/10.1155/2018/3169431.

23. Badr GM, Al-Mulhim JA. The protective effect of aged garlic extract on nonsteroidal anti- 
inflammatory drug-induced gastric inflammations in male albino rats. Evid Based Complement Alt Med 2014. Article ID 759642, 9 pages. http:// dx.doi,org/10.1155/2014/759642.

24. Okada Y, Tanaka K, Fujita I, et al. Antiodidant activity of thiosulfinates derived from garlic. Redox Rep 2005;10:96-102. doi: 10.1179/ $135100005 X 38851$.

25. Borlinghaus J, Albrecht F, Gruhlke $\mathrm{MCH}$, et al. Allicin: chemistry and biological properties. Molecules 2014;19:12591-618. doi: 10.3390/ molecules190812591.
26. Chang $\mathrm{SH}$, Liu CJ, Kuo $\mathrm{CH}$, et al. Garlic oil alleviates MAPKs- and IL-6-mediated diabetesrelated cardiac hypertrophy in STZ-induced DM rats. Evid Based Complement Alt Med 2011:e2011. Article ID 950150, 11 pages. doi: 10.1093/ecam/ neq075,

27. Hamlaoui-gasmi S, Mokni M, Limam N, et al. Grape seed extract mitigates garlic-induced oxidative stress in rat spleen and plasma. J Med Plants Res 2011;5:6076-84. doi: 10.5897/JMPR11.1035. 